\title{
Falling in love in absentia: \\ Grimalte and Gradissa's \\ mimetic desire in Juan de Flores' \\ Grimalte y Gradissa
}

\section{Enamorándose in absentia: el deseo mimético de Grimalte y Gradissa en Grimalte y Gradissa de Juan de Flores}

\author{
Luis Fernando López \\ Harvard University
}

Juan de Flores' Grimalte y Gradissa is a story in which the dramatic tension is sustained by desire and by the active drive to bring that desire into fruition. Flores readapts Boccaccio's protagonists, introducing them into his own diegetic world to attempt an intertextual reconciliation. As the drama unfolds, Fiometa's desire for Pánfilo and Pánfilo's "desire" for Fiometa are mimicked by Flores' eponymous characters. Gradissa sends Grimalte to attempt their reunion. Like Gradissa had fallen in love with Pánfilo in absentia, Grimalte falls for Fiometa. This study argues that Gradissa sends her courtier to Italy because she is secretly in love with Pánfilo. Grimalte accepts her command in order to earn Gradissa's favor. In the process Grimalte falls in love with Fiometa.

KeYwords: Mimetic desire, Amor de Lonh, Identification, Courtly Love, Juan de Flores

Grimalte y Gradissa de Juan de Flores es una historia en la cual la tensión dramática se sostiene por el deseo y el impulso activo de concretar los deseos eróticos de los protagonistas. Flores readapta los protagonistas de Boccaccio, insertándolos dentro de su propio mundo diegético para intentar una reconciliación intertextual. Durante el desarrollo de la trama, el deseo de Fiometa por Pánfilo y el "deseo" de Pánfilo por Fiometa son mimetizados por los personajes epónimos de Flores. Gradissa envía a Grimalte para intentar el reencuentro romántico entre los personajes boccaccianos. Así como Gradissa se enamora in absentia de Pánfilo, Grimalte se enamora de Fiometa. Este estudio arguye que Gradissa manda a su caballero a Italia porque está secretamente enamorada de Pánfilo. Grimalte acepta su mandato con el fin de lograr el amor de Gradissa. En el proceso Grimalte se enamora de Fiometa.

Palabras Clave: Deseo mimético, Amor de Lonh, Identificación, Amor cortés, Juan de Flores 
$\mathrm{J}$ uan de Flores' fifteenth-century sentimental romance Grimalte y Gradis$s a$ is a story in which the dramatic tension is sustained largely by desire and the active drive to bring the desire into fruition. Grimalte "loves" Gradissa, and he is willing to (and does) go to the end of the world to advance his prospects of achieving his romantic goal. Like Grimalte, Fiometa, whose characterological autonomy, in Joseph E. Gillet's words, escapes the control of both her author (Boccaccio) and her husband to embark on an erotic pilgrimage to find Pánfilo, treading long and painful distances in order to satisfy her forbidden passion. The tale exhibits an apparent straightforward plot: Grimalte desires Gradissa, and Fiometa lusts for Pánfilo. After Pánfilo rebuffs Fiometa, she kills herself, and Gradissa rejects Grimalte because she believes her erotic life is interlaced with that of Fiometa. She fears that if she accepts Grimalte, she risks being abandoned and dead like Fiometa. The novela ends with Pánfilo and Grimalte atoning for their self-loathing guilt in the wilderness of Asia. For over five centuries scholars have not questioned the deceptive simplicity of the characters' amorous desires, despite critics' caveats of linguistic relativisms in Flores' literary texts. ${ }^{1}$

The purpose of this study is to advance a hermeneutics of Grimalte and Gradissa's desire based on fifteenth-century and contemporary theories of "mimetic desire". Flores' scholars have taken at face value Gradissa's assertion that she empathetically identifies with Boccaccio's heroine Fiometa, and selflessly sends her suitor, Grimalte, to a dangerous journey to reunite the Italian lovers. By interpreting Grimalte and Gradissa's love affair through the prism of mimetic desire and the medieval topos of Amor de Lonh, the reader can sense a shift of erotic paradigms and goals, where the eponymous lovers redirect their desires to fit those of Pánfilo and Fiometa. This study contends that Gradissa, indeed, identifies with Fiometa to the point of ontological syncretism, but not because she feels pity for her bathetic and illicit passion for Pánfilo. Rather, through a complex process of affective mimesis, as advanced by Girard's theory of the "triangular” desire, Gradissa copies Fiometa’s desire for Pánfilo,

1 Pamela Waley ("Introduction", 1), for example, sees the rift between word, action and intention in both Grisel and Grimalte: "One of Flores' assumptions in both his novels is that what people say and do does not necessarily coincide with what they think and intend, and the application of this to the action of the novels results in a sophistication of characterization akin to that of La Celestina”. See also López González “The Defection of the Word”. 
and her sensual desire for the Florentine lover impels Gradissa to send her courtly lover to reconcile the Italian couple. Like Gradissa, Grimalte simultaneously falls in love with Fiometa and mimics her desire for Pánfilo.

Although Patricia Grieve (Desire and Death, 75) does not find any contagion of desire in Flores' romance, she notes that "Grimalte y Gradissa [...] embodies the conflict of mimetic desire". Desire, as Girard points out, has a built-in conflictive nature, often perceptible in what he calls the "double bind", where the subject concurrently invites and rejects the Other to imitate his desire (Girard, Violence, 147). Although mimetic desire is not self-evident at first glance, once identified it helps readers understand Grimalte and Gradissa's behavior in ways that seem to conflict their axiological worldviews: Gradissa compels her noble lover to undertake a demeaning quest as go-between, and Grimalte betrays his courtly love conduct by praising and placing Fiometa's intrinsic value above that of his beloved's. Mimetic desire, then, overarches Flores' novela, and interindividual contagion is ubiquitous throughout the text.

Critics tactfully note Flores' condemnation of the irrational behavior of his characters. Rina Walthaus ("Espacio", 10) interprets Gradissa and Pánfilo's respective rejections to Grimalte and Fiometa as the quintessence of reason vanquishing passion. In line with Matulka's interpretation of Gradissa as archetype of the belle dame sans merci, Vera Castro Lingl allots to Gradissa the crown of cruelty for subduing her passion: "Only Gradissa escapes punishment, since she opts to wear the Crown of Cruelty by not giving in to her desires" ("Fiometa's", 347). When Walthaus and Castro Lingl argue that Gradissa does not give in to her passion, they mean that she does not accede to her "feelings" for Grimalte. However, both her attitude and words suggest that she does give in to her desire for Pánfilo, and this transgressive desire becomes the catalyst for Flores' novela and for Gradissa's irrational resolution to send Grimalte to perform an anti-courtly quest as panderer.

Marina S. Brownlee stresses that Boccaccio's Fiammetta wrote her Elegia in order to serve as anti-Galeotto, i.e., to warn ladies against men's deceits. However, the Elegia does not serve her intended purpose: "In an obvious sense, however, her text is a Galeotto [go-between], since it is her reading of the Heroides and Metamorphoses that has incited her passion" (Brownlee, The Severed, 178). Just like Ovid's tales enabled Fiammetta to fall in love, Fiammetta's Elegia induces Gradissa to fall in love with Pánfilo. The Galeotto motif, as René Girard articulates it, is a mimetic phenomenon. Each intertextual reader becomes infected by the desire of the literary Other, until it gets to the romantic reader, in this case, Gradissa: "Paolo and Francesca are dupes of Lancelot and the queen, who are themselves the dupes of Galleot. And the 
romantic reader, in their turn, are dupes of Paolo and Francesca. The malignant prompting is a process perpetually renewed without its victims' being aware of it" (Girard, To the Double, 2). This "malignant" mimesis occurs because it uncovers a preexisting desire, and the personified book serves as procurer or catalyzer of desire. Like the Galleot, the Elegia serves its purpose as etiological matrix of desire. Once "unknowingly" infected, Gradissa needs an enabler to help bridge the chronotopic distance that separates her from her object of desire, and Grimalte, who is bound under the principles of courtly love to be a servant to his lady, fits the description to become a metonymic extension of the Galleot, which is both the cause and the effect of desire.

The literary motif of falling in love by hearsay (Amor de Lonh), as articulated by Jaufré Rudel's apocryphal Vita, was pervasive and controversial in the 134 Middle Ages. Love by hearsay, which epistemologically opposes the preponderance of sight in falling in love, was a point of contention in the Middle Ages, after Rudel's erotic pilgrimage to Tripoli "per voluntat de liei vezer" (Cirlot, "El amor de lejos"). In his classical study on Rudel, Leo Spitzer underscores the spirituality that characterized Rudel's relationship with the Countess of Tripoli, arguing that his relationship with the Countess depended on an eternal state of non-possession (Leo Spitzer, L'amour). ${ }^{2}$ We could argue that Gradissa's desire for Pánfilo is also spiritual or neo-Platonic in essence, but her desire does seek sensual gratification, if only vicariously.

In his chapter "Love by Hearsay", Girard (The Theater, 90) underscores the importance of words (written or oral) in catalyzing desire in the receptor. Applying Girard's theory of desire to Flores' Grimalte, Brownlee asserts: "Whereas the earlier [the Elegia] explicitly presents itself as anti-Galeotto but is a Galeotto in reality since it chronicles Fiammetta's alternately praised and despised capitulation precipitated by books" (Brownlee, The Severed, 178). ${ }^{3}$ The Elegia, then, is a tale that incites to love, and that is precisely the effect it has on Gradissa and perhaps in Grimalte. Inflamed by Fiammetta's ardent desire for Pánfilo, Gradissa conceives her desire for the seductive Florentine through the mediation of Fiometa's irrational passion, which has led her to abandon axiological codes of conduct, husband and Self in her quest to fulfill

2 Cirlot makes a similar claim about love from afar: "El amor de lejos es el amor del corazón, con lo cual se alude a su invisibilidad".

3 Then Brownlee adds: "the book, in this case the Elegia, is intended by Grimalte as a Galeotto by which to win the favors of Gradissa. He assumes that she will, by reading it, come to identify Fiammetta's unrequited love with his own" (179). Grimalte's plan, however, backfires, for the book served the purpose with the wrong man. 
her erotic desires. Ironically, Grimalte's fate at the end of the story mirrors that of Fiometa because, as Mirabella promises Grisel after his altruistic suicide in Flores' other novel Grisel y Mirabella, his love for her spurs him to follow her to death (Flores, Grisel, 85).

Before delving into the critical analysis of the text, it is important to establish a theoretical framework to help us understand the phenomenological theories of desire as advanced by René Girard. Grieve (Desire and Death, 2728) has already pointed out the predominance of mimetic desire in Diego de San Pedro's romances and also in Flores' Grisel y Mirabella and Grimalte y Gradissa. However, she centered her attention on the problem of desire and its interplay with the Jealous Rival, but it is fundamental to focus on the hermeneutics of desire to explore the way in which people fall in love with representations of people they have not seen before. For such interpretation, we will briefly turn our attention to the topos of Amor de Lonh, for which Rudel's and Dante's Paolo and Francesca's stories will be essential.

As Grieve notes, Girard's epistemology of desire helps us comprehend the extent to which Flores exploits human emotions and passions to enhance the psychosexual makeup of his characters. For the French critic, desire represents the matrix of human emotions and sexual drives by conditioning and policing human behavior. In his seminal monographs Deceit, Desire and the Novel and Violence and the Sacred, desire is centered at the very core of his epistemology, and then he expanded it in works like The Theater of Envy, an exegetical work of Shakespeare's plays, and To Double Business Bound. Rivalry, according to Girard and to the fifteenth-century Spanish exegete Alfonso de Madrigal, does not arise because two desires converge on one object. Rather "the subject desires the object because the rival desires it" (Girard, Violence, 145. Girard's emphasis). The "triangular" desire, as he postulates it in Deceit, Desire and the Novel, is formed by a couple (Pánfilo-Fiometa), one of which serves as mediator or model (Fiometa), and the third person (Gradissa) mimics the desire of the model. The model, Girard avers, turns into a model/obstacle/rival of mimetic desire. In his chapter "O Teach me how to Look", Girard offers an example of this phenomenon in the crisscrossed desires of Helena and Hermia for Demetrius:

To Helena, Hermia is the model/obstacle/rival of mimetic desire; the mediated subject is hysterical because of her extreme frustration at the hands of her victorious mediator (The Theater, 43-44).

The success of desire, or lack thereof, depends upon the effectiveness of rivalry. Alfonso de Madrigal, El Tostado, had already diagnosed the effects 
of rivalry in mimetic desire. Anticipating Girard's theory of mimetic desire by over five centuries, the Spanish exegete explains:

El amor declaramos ser passión más fiera e más impetuosa que todas las otras passiones, enpero esta feroçidad e ímpetu suyo mayor fuerça tiene quando en la cosa amada hay otro competitor, convién saber, que ansí como nós la ame, entonçe el amor se faze más crudo et más fiero et a todos los trabajos se pone (Madrigal, Breviloquio, 19).

Madrigal understands love as a mimetic phenomenon. When a rival ("combrueço") — real or perceived-meddles in the relationship, the desire then becomes mediated through the lens of the rival. It is no longer a direct and pure desire based on the intrinsic value of the beloved. Rather, it becomes a desire filtered through the desire of the Other, a desire which is a mere counterfeit or a specular reflection of the Other's desire. And this is precisely the type of desire that is at stake in Flores' Grimalte, one that lacks both depth and originality, and this is precisely the reason Grimalte and Gradissa's relationship is destined to fail. Their desires are both inauthentic and mediated through the desires of others, impelling them to shift and reorient their desires to the Other. In a study where she argues that the identity of the medieval man was constituted and influenced by written (or oral) identification with previous (historical) characters, Diane M. Wright explores the importance of intersubjectivity in Flores' Grimalte. Wright argues that the power of the written text, such as Fiammetta, shapes the intra- and extradiegetic attitudes toward seduction or lack thereof: "Fiometa's story has become the organizing principle around which the characters order their love affairs" ("Readers", 233). Wright is right pointing out the preponderance of Boccaccio's autonomous characters conditioning and fashioning the way in which Flores' characters shape their desires and their passions by means of mimetic desire.

\section{Gradissa’s Mimetic Desire for PÁNFilo}

Alluding to Quixotism and Bovarism, literary concepts of which Paolo and Francesca, and Grimalte and Gradissa are examples avant la lettre, Girard argues:

If the hero lived in the same world as the model instead of being forever distanced from him by myth or history, as in the examples above, he would necessarily come to desire the same object. The nearer the mediator, the more does 
the veneration that he inspires give way to hate and rivalry. Passion is no longer eternal. A Paolo who encounter Lancelot every day would no doubt prefer Queen Guinevere to Francesca unless he managed to link Francesca and his rival, making the rivals desire her, so as to desire her the more himself - to desire her through him or rather against him, to tear her, in short, from a desire that transfigures her (To the Double, 3, my emphasis).

By merging both stories into one, Flores bridges the spatial and chronological barrier between his characters' interindividual desires. Although it is nearly impossible to pinpoint the precise moment Gradissa fell in love with Pánfilo, the narrator's clues are purported throughout the story. The interindividual con-fusion is established from the very introduction to the text. The lovesick Grimalte explains his predicament to the reader:

Por la cual causa, venida su muy graciosa scriptura a la noticia de una señora mía llamada Gradissa, las agenas tristezas tanto la apasionaron que ella no menos llagada que aquella otra [Fiometa] se sentía (Flores, Grimalte, 91).

Grimalte points out the power of the written word to evoke (com)-passion, and through the imagery conveyed by literary discourses, Gradissa becomes impassioned to the point of feeling (se sentía) hurt by Pánfilo as if she were Fiometa, a literary conceit that Rojas exploits in his Celestina. ${ }^{4}$ Robert Folger demonstrates how the premodern reader formed mental images in the process of reading, which enables readers to fall in love in a similar way one would through visual perception. Interpreting this fragment, Folger argues that Boccaccio's “'sciptura' engenders in [Gradissa] 'compassion”" (Images in Mind, 178-179). Folger, however, only underscores Gradissa's self-delusional avowal that her intentions are informed by her inherent kindness and not by self-interest. Critics have noted Gradissa's mens rea and lack of compassion in the story. ${ }^{5}$ This does not mean that Gradissa in incapable of empathy.

4 When the go-between is acting out in order to seduce Calisto and get more money out of him. She points out Sempronio's alleged doubling with Calisto and his ability to feel the same pain: "No me congoxes, ni me importunes, que sobrecargar el cuydado es aguijar al animal congoxoso. Ansí sientes la pena de tu amo Calisto, que paresce que tú eres él y él tú, y que los tormentos son en un mismo subjecto" (Rojas, Celestina, 118). For further analysis regarding mimetic desire in Celestina, see Sutherland's "Mimetic Desire").

5 Walde Moheno ("La experimentación”, 82) sees Gradissa as a kind of demon: "una suerte de demonio”. See also Alcázar López and González Núñez, in their Introduction to Juan de Flores, Grisel y Mirabella ("Introducción”, 34): “Gradissa, a su vez, no es ya la dama-diosa,

Medievalia 48, 2016, pp. 131-156 
However, she does not perform any acts of benevolence throughout the story, which makes it unlikely that sending her lover to a demeaning quest is the only act of compassion of the novel.

Folger is right, though, noting that it is through these mental images that Gradissa is able to imagine and identify with Fiometa. It is, however, an identification conditioned by and the expression of the deep-rooted desire that the Neapolitan lady harbors toward Pánfilo. Gradissa copies and appropriates her desire, impelled by the aura of sex symbol that both Boccaccio and Flores bestow upon the Florentine lover. Lacarra sees an affective identification from Grimalte to Fiometa when Grimalte bitterly complains to the Spanish lady that he does not possess the same power of articulation or literary ingenuity as Fiometa. If he were as creative and ingenious as Fiometa, Grimalte objects, "soy cyerto que vos ya fuerays mía, sin haver de hir agora a los stranyos reynos a conqueriros" (Lacarra, "Juan de Flores”, 229). In this vague objection, Grimalte says that he is going away to Italy to gain Gradissa's favor. His words are figurative, rather than literal, but he conveys them as if Gradissa were in Italy, or rather, as if Gradissa and Fiometa were "two cherries from the same stem" (Girard, The Theater, 41), pointing to an ontological fusion between Gradissa and Fiometa that underscores their sameness (López González, “Grimalte and Gradissa's”).

By means of identification, Gradissa eliminates her ontological differences with Fiometa. Gradissa projects her Self onto Fiometa so that she is virtually injured by Pánfilo's rejection to the Italian beloved. Girard terms this kind of affective identification "ontological desire", or "ontological translation" when one person wishes to be another, as in the case of Helena and Hermia in AMidsummer Night's Dream. ${ }^{6}$ Girard (The Theater, 45 ) argues that "all Shakespearean characters want to be their victorious rivals". Like Helena, Gradissa wants to be translated to Fiometa and become Fiometa, the victorious rival for Pánfilo's desire. Her ontological translation is only on the condition that the Neapolitan lady fulfills her desire for Pánfilo so that Gradissa can live her romance through

compendio de virtudes divinas y humanas, sino una señorita neurótica y caprichosa; inhumana y mandona, que confunde al triste de Grimalte con uno de sus lacayos, y que, más que un enamorado servidor, lo que parece necesitar es un corresponsal en el extranjero o un correveidile". Beyond the sarcasm of the critics, it is difficult to reconcile Gradissa with a compassionate reader when she does not have any compassion for Grimalte who has served her well.

6 Girard (The Theater, 43): "Helena wants to be 'translated' to Hermia. The word is a key one in A Midsummer Night's Dream; it [the word translated] links the ontological desire [i.e., the desire of Being the other] of the four lovers to the mythical metamorphoses of the midsummer night". 
her. For Grimalte (or the reader), it is difficult to detect Gradissa's intentions because she masks her message in a highly encrypted rhetoric:

En sus males pensando, quasi como ella las siento, en special que muchas vezes me veo temerosa que si por vuestra mi diesse, yo misma me daría al peligro que ella tiene (178).

Gradissa's words are often enshrouded in double entendre. Prima facie, her words project a compassionate identification with Boccaccio's heroine, which it does not represent an aberrant or an isolated outlook, given the popularity of the Elegia (Weissberger, "Authors, Characters", 72-73). However, Gradissa confesses that she feels Fiometa's pangs of love as if they were her own or rather, as if she were Fiometa herself. What does Gradissa feel, like Fiometa, that hurts her? It is not just the pain inherent in love, which nearly always ends in tragedy in Flores' fiction. It is Fiometa's desire that "quasi como ella las siento", and the "quasi" is an indicator of the lack of originality and depth of her desire. In this affirmation, she achieves a double purpose. First, she avows an erotic identification with her model/obstacle/rival, which amounts to confessing her mimetic desire for Pánfilo. Second, she outlines the intricate plan for getting rid of her suitor and sending a vicarious extension of herself to Pánfilo. But she encrypts and codifies her message in a way that she misleads Grimalte and readers alike.

Just like Fiometa is the mediator of her desire for Pánfilo, Grimalte becomes the agent/mediator and enabler of her mediated desire, so that Grimalte assumes the paradoxical role of go-between, while literally standing between her and Pánfilo. Grieve (Desire and Death, 92) believes that "Fiometa is the unwitting mediator of Gradissa's final stance of non-desire. Gradissa avoids the pitfalls of mimetic desire and shows herself to be the ideal moral reader, one who benefits from the example of another's misfortune". The difficulty with assessing critics' opinions about mimetic desire in Gradissa's case is that they never factor Pánfilo into her psychoaffective life. Fiometa is the mediator of Gradissa's non-desire for Grimalte, but Fiometa becomes the mediator/ model for the pitfalls of Gradissa's mimetic desire for Pánfilo. The authenticity of her desire for Pánfilo, however, is difficult to assess since it is a mere shadow of a genuine desire.

During their first encounter at the beginning of the story, the narrator asserts that Gradissa is not in love with him. After narrating how Grimalte is spending his life wooing her, the narrator/protagonist confesses: "Tanto que yo desto puedo alabarme, que yo de más constante y ella de más cruel, ninguno 
igualársenos pudo" (91). The accusation he marshals against Gradissa's cruelty is neither accidental nor exaggerated. Gradissa's "disdain is clearly explained" (Severin, "Audience”, 64). Gradissa's lack of empathy represents a defining characteristic of her self-fashioning as courtly beloved, and it overarches the entire novel. Grimalte's perceptive intuition that she is cruel and not in love with him will be evident throughout the story and underscored at the end. The reader can even feel a sense of Gradissa trying to set Grimalte's feeling on Fiometa by asking him to deflect his amorous desires toward the Neapolitan lady. ${ }^{7}$

Gradissa's first inclination is to go to Italy herself with the excuse of enabling their reconciliation ("la voluntad me manda"), but her "vergüenza me lo estorba" (93). These two axiological imperatives exemplify the psychological tension or the double bindedness, as advanced by Bateson's theory, of her 140 predicament. If she goes, she will suffer irreparable social disrepute, for noble ladies ought not to expose themselves to the evil tongue of defamers by going after lovers-like Fiometa's aberrant behavior, which Dinko Cvitanovic ( La Novela, 278) sees as an inversion of traditional gender roles. If Gradissa stays, she will not fulfill her erotic desire to see her Pánfilo, which would, by being close to Fiometa make her desire him even more. To avoid defamation, Gradissa opts for escaping the double bind by sending an extension of herself (Grimalte) to serve as "tercero". Louise M. Haywood points out Gradissa's compassion for Fiometa, but she also argues that Gradissa empathizes "with her as a lover. Her self-identification with Fiometa is so extreme that she also equates their lovers' behavior" ("Gradissa", 85-99). Haywood is right, for Gradissa perceives Fiometa both as double and as rival. Fiometa is for her an ontological desire, i.e., she wants to be Fiometa to enjoy Pánfilo's love.

Consciously (or unconsciously), Gradissa offers herself as the third ("tercera"), which is a literal appropriation of the third point in the "triangular" desire. By avowing that she wants to be the tercera, she is subconsciously putting herself forward to occupy the third post of the triangle:

7 When she asks him to go unite them, she says: "El cual es bueno que sea disponer vuestra persona en favor de Fiometa y que muestren vuestras obras con ella los desseos que para me recuestar mostraste" (93). And later: "Y a vos tan sin amor ha tornado que mi mal avéis por bien tanto como la que mi muerte dessea. Agora Nuevo cuidado me dais, y no vencida de desseo y piedad de Fiometa os moveis, mas por verso descansar con mis absencias algún tienpo sin rescibir mis recuestas" (97). Grimalte interprets correctly Gradissa's intentions. First she is not in love with him and second she wants to get rid of him, but more than getting rid of him, she wants to bring Pánfilo close to her through written means. In other words, Gradissa wants to extend the love story between the lovers, which is why Rojas decided to continue his Celestina. 
Y pues, dizen su partida en busca de su amante, paresceme ser tiempo de aver menester tercero que sus amores conforme, y bien quisiera yo ser aquella tercera, si el freno de la vergüença no me templara (94).

Gradissa discursively posits herself as a go-between ("tercera"), but she literally wants to go between the two lovers and be the tercera in the "triangular" desire, and then become la primera (the first) — so long as Pánfilo can retain Fiometa's modeling/rivaling desire. The moment Fiometa despises Pánfilo, Gradissa's passion evaporates, for in mimetic dialectics, desire follows desire, not people. Her "vergüenza", a defining characteristic of Mirabella (López González, "Mirabella's Deadly Gaze") tempers, but does not eradicate her desire for Pánfilo. In order to go between them, Grimalte has to become a vicarious agent and a metonym of her desire:

Y vos trabajad que Fiometa le aya tal y tan próspero, que yo me desee ser ella [...], así que ella me será un espejo de doctrina con que vea lo que con vos a mí conviene fazer (95).

The subjunctive "desee" already points out the dislocation of desire and how unrealistic her feelings for Pánfilo are. Gradissa longs to be Fiometa, but her "deseo" does not signal ontological desire. Rather, meta-desire is at stake here, for Gradissa desires Fiometa's desire for Pánfilo. In other words, it is not an appropriation of Self what Gradissa pursues, despite her overt allusions of wanting to be her. Instead, she seeks an appropriation of her desire, and the word "espejo", which is a tangible mechanism of doubling, underscores the referentiality of both desires. Walde Moheno ("La experimentación”, 75) points out Flores' deployment of an innovating use of generic narrative resources of "reduplicación" and "triplicación" in Grimalte. And the redoubling of desire is only an expression of the author's penchant for creating specular imagery of duplicity and doubleness. The "espejo", which is a ubiquitous presence in the text, represents the perfect metaphor in the imagery of Gradissa's mimetic desire, for only Fiometa's love is authentic. Gradissa's desire is but a poor reflection of Fiometa's, which allows readers to understand why Gradissa's desire for Pánfilo is both unavowed and even hollow, which does not mean that it is non-existent. Like a reflection in a mirror, which can only exist provided that a physical object stands before it, a desire can only subsist on the condition that the other desire remains fixed upon a common object. The last sentence only confirms Waley's interpretation that whatever the outcome of his quest, Gradissa would not have accepted Grimalte as lover. 
Grimalte is an ineffectual reader, and that could be the reason he, unlike Gradissa with Pánfilo, did not fall in love with Fiometa in absentia, despite her privileged position in the limelight of the Neapolitan court and her unduly success with courtly lovers. A more discerning reader-like the many whom he found in the villages paining for Fiometa's love-would have fallen in love with Fiometa. Just like he misconstrues Fiammetta's Elegia as a Galeotto, he is self-delusional by interpreting Gradissa's command as an act of compassion, which represents an apparent contradiction to his previous statements regarding Gradissa's intentions to get rid of him. ${ }^{8}$ Grimalte misapprehends Gradissa's intentions because, justlike Fiometa, he is desperate to beloved. During his first encounter with Fiometa, before the dramatic anagnorisis, Grimalte tells her:

Pues era a mí manifiesto, Fiometa segunt escrivió, partirse en busca de su amante, pues a las damas del mundo requiere por piadoso remedio, que sería crueza e infamia de mugeres si no fallase una que de los males suyos compassión oviese, de los cuales ella más que otra se quería doler (109).

By telling Fiometa that Gradissa was moved by compassion and not by desire, Grimalte avoids the pitfalls of Fiometa perceiving Gradissa as a rival, which could render her (and by extension Grimalte's) mediation unwelcomed. But unconsciously, he is declaring Gradissa's desire to the incognito Fiometa because Gradissa's self-projection amounts to mimetic desire. As Girard (The Theater, 312) notes: "To Shakespeare... we not only misunderstand but understand other people by projecting our own sentiments upon them. In Twelfth Night, for instance, Orsino discusses Olivia's desire on the sole basis of his own”. Like Orsino, Gradissa assesses Fiometa's desire for Pánfilo on the basis of her own desire for the Florentine lover. Grimalte does not (or pretends not to) seem to understand how human emotions and desires work, but unconsciously, he keeps uttering ambiguous statements that point to Gradissa's masked passion for Pánfilo. He asserts to the disguised Fiometa:

Porque de conpasión de Fiometa [Gradissa] quería tomar la venganza de su [Gradissa’s] Pánfilo en mí, así que por las faltas agenas fazía yo la penitencia (109).

8 See Weissberger ("Resisting Readers", 183): "Grimalte uses Fiammetta as a tool of seduction, and he succeeds in inflaming his lady's passions with it: 'las agenas tristesas tanto la apassionaban que ella no menos llagada que aquella otra se sentia”. Weissberger, of course, is right in pointing out that Fiammetta is a tool of seduction, but not according to Grimalte's plan. Gradissa becomes inflamed with passion for Pamphilo. The Spanish heroine is Ilagada like Fiometa by the same man. 
Although he continues to allude to her conpasion - a word that was closely related with passion (cum-patio) in Spanish medieval literature-as the catalyst for Gradissa's agency, Grimalte uses the possessive $(s u)$ to insinuate that Pánfilo erotically belongs to Gradissa. The sentence, as it often occurs in Flores' fiction, is syntactically equivocal, but let us remember that grammatically the subject of the sentence is Gradissa. The agent that feels compassion for Fiometa is the unmerciful Spanish belle dame, and Gradissa is the only one capable of exerting any sort of vengeance upon our narrator. Hence Grimalte, even if he does not intend it to, espouses Gradissa and Pánfilo and confers sole possession of the disloyal Italian lover to the Spanish lady.

Gradissa's second and last direct intervention in the text takes place toward the end of the romance. Grimalte had already failed at rewriting the ending of Fiammetta's Elegia to Gradissa's satisfaction, and Grimalte is about to confront Gradissa for his failure as go-between, writer and lover. The narrator represents Gradissa anxiously waiting to receive news of Pánfilo, which mirrors Fiammetta's impatience in Boccaccio's Elegia while she awaited news of her disloyal Panfilo. Gradissa's haste to send Grimalte to Pánfilo as vicar of herself represents a seeming contradiction to the anxiety with which she awaits his return (Waley, "Introduction", 1). Her anxious impatience prompts us to believe that she is impatient because she awaits news of her Platonic lover. In an impersonal tone that underscores her lack of desire for Grimalte, Gradissa writes:

Grimalte, no penséis que vuestra venida me sea tanto enojosa cuanto vuestra tardança me dava pena, en especial, porque alegres nuevas y no tales como agora escrivís, de Fiometa atendía (202).

Gradissa sounds distressed for her lack of information on the matter, but her dreams are shattered by the bad news of the agent of her desire. Without Fiometa, Gradissa understands, she can never fulfill her objective of having a romantic relationship with Pánfilo (even if only a metaphysical Amor de Lonh). Afraid to name the real person she expects news from, Gradissa masks his name with Fiometa's. She wants to know about Pánfilo but asks for Fiometa. Rather than pointing out her disinterestedness, the elliptical reference to Pánfilo only emphasizes her desire toward him. His absence on Gradissa's discourse accentuates his presence. Had she asked for Pánfilo, it would reveal lack of malice and lack of desire for him, but she withholds his name to conceal her overarching passion for the Florentine lover. Along with her longing to know about Pánfilo, Gradissa's epistle shows an utter disaffection and 
apathy toward Grimalte as lover (and even as an individual). Alan Deyermond ("Las innovaciones",98) notes that the reader (us) can see the negative response of another reader (Gradissa), and what we can see is a lady whose hopes of erotic satisfaction with Pánfilo have banished due to Grimalte's ineptitude. But in mimetic-desire discourse, failure to produce an obstacle/rival who desires Grimalte serves as a deterrent for Gradissa's desire for him, while the success of Pánfilo operates as a magnetic force to attract other desires, such as Gradissa's.

\section{Grimalte Falls in Love with Fiometa (and Pánfilo)}

144 If Gradissa mimicked Fiometa's desire with an Amor de Lonh, Grimalte was bound to be infected by the epidemic of desire that Fiometa had spread with the popularity of her Elegia. To deny Grimalte's desire for Fiometa is to take for granted his rare statements where he passionlessly declares that he loves Gradissa and to disregard all his actions and words that convey his desire for Fiometa. Like Gradissa, Grimalte says one thing but thinks something different, a trait both in Grimalte and Grisel. Grimalte uses relativisms in order not to disappoint Gradissa by confessing that he has fallen in love with Fiometa. Alluding to the atoning scene at the end of the novel, Grieve (Desire and Death, 78) notes that Grimalte abandons the pursuit of Gradissa to "emulate" Pánfilo. However, Grimalte's abandoning of Gradissa's pursuit and emulating Pánfilo-at least his unavowed desire - takes place before Grieve indicates. Grieve (Desire and Death, 89), however, is right when she points out that "Grimalte does not abandon his role as imitator, he expands it".

In some ways, Grimalte is a chameleon-like character who adapts and imitates. His physical and ontological imitating at the dénouement is just an outward manifestation of his imitating of Pánfilo's (perceived or real) desire for Fiometa. Parrilla rightfully brands Grimalte as a "poliéndrica figura", for he displays a multiplicity of facets and personalities. However, the main reason he fails at making women love him is because he is unable to produce a single model/obstacle/rival to catalyze the desire of Gradissa, Fiometa (or Pánfilo). His incapability to generate a mediator is not because Flores intentionally fashions his character as "la caricatura del amante a la antigua" (as assert Alcázar López and González Núñez, in Flores, "Introducción", 17-18). Rather, unlike Pánfilo, Grimalte is an ineffectual lover because he can never mask his eroticism with deliberate indifference; he lacks the necessary self-composure to project himself as an assertive and confident person, so his diffidence repels 
women's desires and renders him a bad player in "the game of courtly love" (Macpherson, "The Game", 97). Though not effectively producing a model/ rival, indifference gives the impression to the outer world that a rival exists, which creates a perceptual illusion of a mediator of such desire, as Pánfilo confesses to Fiometa in his letter. ${ }^{9}$ Hence, "indifference plays a role in the genesis of these desires" (Girard, Deceit, Desire, 47).

Alluding to their sharing of "la vida de salvaje" at the end of the novel, Deyermond (Tradiciones, 28) asserts that Grimalte "decide imitar [a Pánfilo]". More than physical or behavioral imitating, the mimicking is also affective. Before Fiometa reveals her identity when Grimalte found her in the deserted crossroads of Italy, the Spanish knight feels an uncanny sensation of déjà $v u$, as if he had seen Fiometa before. ${ }^{10}$ Grimalte recognizes her features because, as Girard and Brownlee note, she has never stopped gazing at herself in her Elegia, and Grimalte has internalized Fiometa's image as described by her autopoiesis (her poetic self-fashioning), and he refers to her as an "espejo de beldad". Just like she cannot stop looking at herself, Grimalte seems not to be able to stop looking at her through that espejo de beldad that seems to have engulfed him in the bottomless reflection of the glass of Fiometa's stunning mirror, a symbol of her eyes and of descent (Frye, Secular Scripture, 71-72).

Isabel de Sena ("Subita volvitrice", 342) notes that in the process of moralizing Fiometa's allegorical tomb, Grimalte "se ha traicionado de hecho así mismo, pues ha cambiado su visión de Fiometa como 'speio de beldat'. I would argue that his shift of perspective regarding Fiometa consists of going from seeing her as a poor dejected lady in need of a procurer to a mirror of beauty that he cannot stop desiring. This passionate shift, however, as Sena notes, takes place during their first encounter in the wild crossroads near Florence, where he perceives her as a mirror of beauty. The leitmotif of the mirror as a doubling device reappears again to showcase the redoubling of desires that lack both authenticity and depth. Grimalte's desire, however, appears

9 Pánfilo openly tells Fiometa that the length of time without seeing her was causing (sexual) desire for her. By not avowing her desire, Pánfilo sensed indifference, which caused desire thinking that there was a rival, but when Fiometa comes to seek him out, the illusion of indifference and rivalry disappears, and his desire disappears with it: "Y por la largueza del tiempo que no te vi, ivan cobrando algún reposo mis desseos, mas agora tu venida las viejas llagas me refresca" (125).

${ }^{10}$ It is highly symbolic that Grimalte recognizes Fiometa in the middle of nowhere without ever having seen her before: "Y como aquel que en busca de cosas perdidas va y las agenas le parescen suyas, no menos a mí los semblantes de aquella me parescieron a los que yo buscava" (105). 
always displayed enshrouded in equivocal discourse and oblique allusions throughout the story.

After Grimalte and Fiometa reveal each other's identity, the dejected lovers feel compelled to explain to one another their presence in such a locus terribilis, which the author consciously introduces as a metonym to their affective and psychological lives. Paradoxically, their courtly love ideals - the axiological expression of a refined culture and civilization - find their mode of expression in the locus of savagery and animalization, a dislocation that points out Fiometa's subversive behavior against patriarchal pre-established social norms and Grimalte's needy willingness to do anything to be loved. His affection toward Fiometa becomes perceptible in his first letter to Gradissa. Grimalte's ekphrastic description to Gradissa stresses Fiometa's beauty and nobility:

A la fin, esto concluyo, la memoria ya puesta en su gentil parescer fizo olvidar la grandeza de mi trabajo, pero cuando ella conosció en mí desseos a su servicio, cessadas ya las usadas ofertas en los nuevos conoscimientos, con gracia más que graciosa la causa de mi venida pregunta, a quien respondiendo dixe assí. Porque como la vide sepáis mi alteración, a bueltas de mi respuesta, aquestos pequeños metros descobrían la celada que el triste mi corazón tenía a la sazón (107).

Although the reader should be mindful of the courtly love dialectics at play that Flores weaves in Grimalte's plot, which promote courtesy and subservience as inherent tenets of conduct, it is precisely the violation of such codes of conduct that gives the reader the tools to interpret Grimalte's evergrowing passion for Fiometa. Grimalte's unconsciousness betrays him in many of his descriptions. ${ }^{11}$ The first sentence of his letter already underscores his desire for Fiometa ("cuando ella conoció en mí desseos a su servicio"). The literal sense may simply refer to Gradissa's request to redirect his desires toward Fiometa, but in a symbolic realm, it points out his erotic desire that has sprung, like Fiammetta's for Panfilo in the Elegia, from her overwhelming beauty that has penetrated from his eyes to his heart. Grimalte's words afford us such ocular-oriented hermeneutics, for as soon as he sees her, he experiences an ontological suspension (alteración) that betrays the impassioned vortex that he feels in his heart. Just like Grimalte, Fiammetta, Fernando Gómez

11 Let us remember that when Grimalte is whining to Gradissa about her commission to travel to Italy, Grimalte had said referring to Fiometa: "Que si Dios a mí de [Fiometa's] gracias alguna parte me diere..." (98). Although Grimalte is alluding to her talent as writer, it is revealing that he unconsciously wants God to confer upon her Fiometa's graces, i.e., her love. 
Redondo ("De la imaginación”, 245, my emphasis) notes, "cuando divisa a Panfilo en el templo, pierde la conciencia de sí misma”. Boccaccio’s Fiammetta and Grimalte's process of falling in love mirror each other. ${ }^{12}$ The words "desseos" and "servicio" refer to codified symbols of subservience and love toward the beloved in courtly love literature. A lover confers "servicio" to his beloved as an explicit avowal of her intrinsic dominance upon him. Grimalte, then, writes a poem fraught with eroticism and overt allusions to her beauty. This ecstatic fascination with Fiometa is even more revealing when we hear Grimalte nonchalantly speaking about his love for Gradissa in the past tense. ${ }^{13}$ After disavowing Gradissa's love and before knowing he was speaking to the "real" Fiometa, he confesses that he yearned to meet her:

Especial, que me fue partido, segund que yo desseava de conoscer aquella tan amadora, y aun, que fallando a mis passiones conpañía, a mí y a ella serían consolaciones (110).

Grimalte's confession that he longed to meet Fiometa undermines the established assumption that he merely follows Gradissa's commands. Waley and Brownlee are right in pointing out that Flores uses relativisms as an innovative literary conceit, which adds verisimilitude to the narrative but always has the potential of misleading readers and characters. Grimalte's affirmation that he wants to find a partner for his passion to console each other amounts to confessing his desire for Fiometa. Fiometa's passion, which Gradissa counterfeits and Grimalte desires, begins to infect Grimalte so that he simultaneously imitates her "passiones" for Pánfilo and falls prey of her beauty, so that he comes to love both the desire (for Pánfilo) and the subject of the desire (Fiometa). But if this sentence masks his intentions with abstruseness, in the poem that ends his monologue ("tomando a vos por espejo"), in which he declares that it fits her description to perfection, he overtly expresses his fascination for her. ${ }^{14}$

12 If Grimalte had felt desire for Fiometa before meeting her, seeing her only reinforced his desire for her. In Boccaccio's Libro de Fiameta, the Italian heroine asks a rhetorical question to assure that love at first sight exists: “¿Quién creería ser possible tan en un punto assí un coraçón alterarse? ¿Quién diría que persona jamás nunca vista se puede amar grandemente en la vista primera?” (Gómez Redondo, “De la imaginación”, 246). Like Fiameta, Grimalte can attest to the power of vision for falling in love or for reinforcing a preexisting condition.

13 Grimalte confesses to Fiometa: "pues ansí es que el tiempo de mi triste vida en servir a una señora fenescí, y las passiones por ella recebidas ninguna comparación lievan” (108).

14 Although critics will object that Flores did not write the poems - as Alonso de Córdoba wrote them-, ignoring them or disregarding them will be a mistake. And as critics note, 
Ironically, when the anagnorisis takes place, Grimalte experiences a kind of loss of self-recognition. He feels a momentary suspension of his rational faculties that portends his descent into bestiality in the dénouement when he conscientiously becomes Pánfilo's demonic double. ${ }^{15}$ Grimalte feels so enthralled with her presence that, contrary to what he says to Gradissa, he confesses that the pleasure he receives from gazing at Fiometa exceeds the burden of his journey:

Aunque Amor en pago de mis males otro gualardón no me diese sino ser causa de veros, tanto contento me haze que por sólo ello me abliga sin otro mérito a servirle. ¡Y qué más bienaventurança de la que yo rescebí espero en hallar a vos, recuerdo de mi descanso! (117).

148 Instead of resentment toward Gradissa for exposing him to such a scornful and ridiculous quest, Grimalte expresses gratitude for granting him the opportunity of seeing Fiometa. His bitter complain that Gradissa is acting out of malice to get him out of her field of vision ("que si algo de fe me toviéssedes guardada, mi vista cercana y no lexos codiciárades” because those who truly love "ante los ojos las tienen en grande seguridad y temen sus peligros", 98) is replaced by ineffable gratitude. Ironically, he is so grateful for seeing Fiometa that he wills to shift his erotic service to literal servitude to Gradissa. And just after feeling blessed ("bienaventurança", a favorite sacro-profane hyperbole in what C. S. Lewis termed "Religion of Love") for looking at her, he reiterates his elation for meeting her and exhibits envy and jealousy toward Pánfilo for having prevailed in achieving sexual intercourse ("alcançado", which is an encoded euphemism in courtly love poetry to signify that they had sex):

Que si en otra manera fuese, no sería partido con igualdad, si alguno de gentil conoscimiento fuese que vos oviera visto y alcançado como Pánfilo alcançó, conosciendo su prosperidad, tanto ensuperveciera que se pensara, con sólo tener a vos, ser adorado del mundo por otro segundo Dios (118).

\footnotetext{
poems in this novel often serve as a summation of what has already been stated in prose: "Si mis terribles enojos / quieren mi muerte vencida, / vuestra beldad y mis ojos / an remediado mi vida. / Vos me distes alegría / con la gentil hermosura, / de manera que asegura / mi plazer que fenescía. / Por lo cual, si mis enojos / tienen mi muerte vencida, / vuestra beldad y mis ojos / an remediado mi vida" (111-112).

15 Frye (Secular Scripture, 93) identifies the imagery of the double with the theme of descent in romances: "We are now coming... into the área of the triws of Doppelgänger figures who are so prominent in descent imagery”. In Grimalte and Pánfilo's case, it is a literal descent into animality and irrationality.
} 
Grimalte conveys his envy and jealousy in a syncretic courtly love codification, which María Rosa Lida called "la hipérbole sacroprofana”. In Grimalte's raptured state of mind, as in Calisto's in Celestina (“ $i$ Mujer? ¡Oh grosero! ¡Dios, dios!... Por dios la creo, por dios la confieso”, Rojas, Celestina, 99), possessing Fiometa amounts to becoming a god. The divinization of Fiometa through perfectly codified courtly love dialectics represents a blatant violation to courtly love axiology from Grimalte, for no other lady is to be (praised) above his lady. By positioning Gradissa below Fiometa in beauty and intrinsic value, Grimalte is expressing his mimetic love for Fiometa, ${ }^{16}$ which is reinforced by avowing his envy for Pánfil ${ }^{17}$ and by adducing that he is a madman for not reciprocating Fiometa's love. ${ }^{18}$ Then, highlighting his sensual desire, Fiometa's mere presence leads Grimalte to compare himself with a monarch: "Mirad cuánto puede vuestro valer, que sólo en averos visto ya me paresce que reino" (114). Equating himself to a king presupposes likening Fiometa to a queen, an empress or even a deity. Grimalte's "fe", the linguistic symbol of unwavering devotion and faith from courtly lovers, is also reallocated to Fiometa, displacing Gradissa to a distant second plane: "Y por señal y prenda que de mi fe vos quede, esta copla siguiente recibid" (119). Fiometa becomes the inspiration and object of his courtly poetry, thus decentering Gradissa from his affection and devotion. And the copla reaffirms his passion for Fiometa and pushes Gradissa to a detached periphery, which mirrors her distant geographical distance.

16 One may think that because Pánfilo rejects Fiometa, Grimalte does not have a mod$\mathrm{el} /$ obstacle/rival to copy his desire from. However, let us remember that the entire diegetic world is infested by men who love Fiometa. And most importantly, in the Elegia, Fiammetta loves Fiammetta. The mirror that she never stops gazing into is a symbol of narcissistic selflove and self-desire. The other question is whether, like Gradissa, Grimalte fell in love in absentia by reading Boccaccio's Elegia or if he, like Panfilo in the Elegia, fell in love after the species of Fiammetta's beauty entered from the eyes into the heart. The simple (and honest) answer is that the reader does not know and will never know because Grimalte is a master of saying one thing and thinking another. For example, he would never confess his love for Fiometa without masking his intentions with rhetorical ambiguities, and since Gradissa is the main reader of his text, his intentions are always clouded by his delusion that he could one day take Gradissa as a second price.

17 "Nunca por mí veo tales aventuras venir sino a aquellos que de sus envidias muero, pero con todo, más contento soy en no tenerlas para no darles más favorable fin que aquellos que, ya teniéndolas, no las saben estimar ni saber cuál es su prescio” (114).

18 Folger (Images in Mind, 183) notes that Grimalte accuses Pánfilo of madness for not reciprocating her love: "Y los que discreto conocer tienen, iuzgando vuestra crueza, os culpan de no claro conocimiento."

Medievalia 48, 2016, pp. 131-156 
During Grimalte's visit to Pánfilo before he visits Fiometa in the convent, the Spanish knight informs Pánfilo that his (dis)repute has travelled wide and far, and all men and women despise him to the extent that nobody wants to be Pánfilo: "Que no siento ninguno tan abatido que se quisiese ser vos" (136). The irony is that Grimalte would love to be Pánfilo in order to inherit the passion that Fiometa has bestowed upon him. But the reason men hate Pánfilo is because they all mimic his desire, and the conceited Italian lover has publicly disavowed his desire for Fiometa. Grimalte's assertion presupposes that when Pánfilo loved Fiometa, all men wanted to be him, i.e., an ontological mimetic desire. Grimalte repeats his courtly love blasphemy by positing the preponderance of Fiometa's beauty over Gradissa. ${ }^{19}$ After Pánfilo decides to reject Fiometa, Grimalte timidly postulates himself as a surrogate but never openly because, as Girard notes, there is always a fear of being perceived as an imitator of mimetic desire.$^{20} \mathrm{It}$ is only after Fiometa kills herself that Grimalte apostrophizes her body as a departed lover:

Tú, gentil Fiometa, no miravas que no a ti sola mataste, mas a mí muerto, que sin esperança dexas, soterraste. Aunque en el mundo quede, de donde ya te partiste, plañiré mi muerta vida fasta que el fin de dolores me haga tu compañero (181).

Finally, he closes his emoting planctus with a song that laments the demise of his desire (for Fiometa): "Lloraré la fin venida / daquesta que muerta veo, / pues la muerte de su vida / dio morir a mi desseo" (182). The double entendre only affirms the deep sorrow he feels for losing his beloved, for if we look back at his words toward Gradissa, Grimalte never attains the level of lyricism and romanticism that he achieves when referring to Fiometa, and his last letter addressed to Gradissa (204-205) confirms it. Instead, he continues extolling Fiometa in detriment to Gradissa to the extent that the Spanish lady's beauty is a mere foil to Fiometa's. ${ }^{21}$ There is no doubt that Grimalte felt

\footnotetext{
19 "Que si puesto caso el morir entreviniera, vuestro espírito, vestido con dulce gloria, conservaría tan eternal companya, con invenciones de muy alegre imaginación de su figura. Pues, ¿cuál de los bienaventurados favorescidos de amor se pueden con vos igualar en aver alcançado tal excellencia a quien ninguna comparación se halla?” (135).

${ }^{20}$ When Pánfilo rejects Fiometa through the letter, Grimalte literally asks Fiometa to dispose of his desire as she pleases: "Tomad alguna esperança en mi desseo a vuestro servicio dispuesto" (131). Later, he would add: "Pues si vos, señora, con vuestro esfuerço me esforçáis y a mí estimáis, yo mejor que otro sabré la salud para tales daños buscar, como aquel que ya dellos muy contento ferido se vee, mis consejos no serán dañosos a vos” (173).

21 See for example, "pues el su desesperado motive a mí mejor que a él conviene acomplir; antes él devía bevir alegre en que tal muger muriese por él que cualquiera puediera pensar que
} 
more pain when he lost Fiometa than when he lost Gradissa, which is symptomatic of the love he bore for the Italian lady in detriment to the Spanish belle dame sans merci. This only attests to Girard's hypothesis that "a Paolo who encounter Lancelot every day would no doubt prefer Queen Guinevere to Francesca”. Likewise, a Grimalte who encounters Pánfilo (and the villagers who loved Fiometa) every day prefers Fiometa over Gradissa.

By way of conclusion, I would like to posit the question if Grimalte also mimicked Fiometa's desire for Pánfilo. Girard points out potential contagion from "fascinating rivals". Girard suggestively argues:

An attempt should be made to understand at least some form of homosexuality from the standpoint of triangular desire. Proustian homosexuality, for example, can be defined as a gradual transferring to the mediator [Pánfilo] of an erotic value which in 'normal' Don Juanism remains attached to the object [Fiometa] itself. This gradual transference is not, a priori, impossible; it is even likely, in the acute stages of internal mediation, characterized by a noticeably increased preponderance of the mediator [Pánfilo] and a gradual obliteration of the object [Fiometa]. Certain passages in The Eternal Husband clearly show the beginning of an erotic deviation toward the fascinating rival [Pánfilo] (Deceit, Desire, 47; “A Midsummer's", 44).

There is no doubt Grimalte shows homosexual feelings for Pánfilo, which might (or not) demonstrate that he transferred some of his feelings from Fiometa to Pánfilo, simultaneously feeling desire for the mediator (Pánfilo) and the object (Fiometa). When Grimalte follows Pánfilo and Fiometa to the "segreta cámara", where Pánfilo makes love to Fiometa in front of the voyeuristic narrator, Grimalte describes the nude lover in homoerotic terms:

El cual, puede quien me oye ser cierto que jamás una persona de tan gentil parescer no nasció, que cierto, las ansias de Fiometa con las gracias de Pánfilo tenían muy legítimas causas de sus desseos (133).

aquél por quien d'amores mueren, más que otro deve valer" (204). Then, when she is being tortured by the demons, he juxtaposes his joy when she was alive to the repulsion and pain when she is being punished: "De tal manera que cuanto su graciosidad en el mundo me era alegre, tanto y más me dava pena el agora remirarla" (219).

Medievalia 48, 2016, pp. 131-156 
Are those "desseos" for Pánfilo’s "gentil parescer" (beauty) mimetic? His passionate tone suggests so. When Grimalte recriminates Pánfilo for his abandonment, he does so by praising his beauty: “iQuién puede miraros que crea en vos tantos males cuantos Fiometa de vos pregona?" (135). His evilness, argues the Grimalte, contradicts Pánfilo's physical appearance. Commenting on the passionate scene, Diane M. Wright ("Readers", 237) notes: "The scene Grimalte so enthusiastically describes bears the mark of his passionate desire as lover". Then Wright says that it is his love for Gradissa, but his desire is rather likelier for Fiometa or for Pánfilo. Gradissa has been replaced and pushed to a peripheral mode of existence, one whose presence is merely felt by her absence and the long physical space that separates them. And after Pánfilo decides to abandon Fiometa before her suicide, Grimalte describes his departure as if he had been Pánfilo's beloved (or at least Fiometa’s ontological double):

Cuando Fiometa, encendida de la furiosa saña, ovo cessado de decir infinitas de sus razones, yo por cierto, no menos de su passión alterado, cuando pude en su favor se estendieron mis palabras, diciendo tales cosas que nunca más osado ni mayor coraçón jamás me vi, pero en las orejas del malvado Pánfilo ninguna presa facían, mas antes muchas cuestiones mas honestas de callar que d'escrivir pasamos. Pero él, fingiéndose el más injuriado, con la mala gracia blasfemando entre sí, se despide, y a ella y a mí solos, desfavoridos dexó (166).

Grimalte reaffirms and ratifies his homoeroticism for Pánfilo with the ensuing lyrical copla: ${ }^{22}$

\author{
¡O llagado coraçón! \\ ¡Espantosa vida vía! \\ ¡Cómo sufre la passion \\ dolor de tanta porfía! \\ ¡O triste sin alegría, \\ malfadado! \\ ¡Quán amargo fue aquel día \\ en que fue a ti enviado! (166).
}

22 Grieve (Desire and Death, 87) rightfully identifies the function of poetry within the text, and in this case it fits her description perfectly: "The poetry is a means of redefining and reaffirming the emotions expressed in the conversations that precede it. Because it is no more than a redefinition, it seems to be more contrived than the poetry of Gradissa and Pamphilo". 
The ontological con-fusion between Grimalte and Fiometa is so imbricated that Waley feels compelled to include a footnote to clarify that it is, in fact, Grimalte and not Fiometa, who is speaking. ${ }^{23}$ Haywood interprets the voice as Fiometa's, but Parrilla agrees with Waley that the lyric persona is Grimalte. The confusion underscores the extent to which Grimalte mimics both Pánfilo and Fiometa's desires for each other and brings us back to Parrilla's description of Grimalte as "poliéndrica figura”. And instants before Fiometa kills herself, he declares himself the heir of her passions (which could be understood both as pain and as erotic desire): “¿Por qué razón avía yo de ser eredero de tus passiones?" (180). It is even more explicit when he finds Pánfilo in the wilderness of Asia. In a stanza fraught with homoeroticism, Grimalte openly confesses his desire:

Consuélate, si tú eres

el Pánfilo que desseo,

que de la angustia que mueres

también yo muerto me veo (211).

If Pánfilo is the man he desires, then, Grimalte undermines his avowed desire for both Gradissa and Fiometa. Grimalte, after all, is not portrayed as excessively feminine, although there are instances that do highlight his effeminate side. But he is also not represented as a virile character, which is one reason he is neither able to secure the desire of a man nor a woman, despite his seeming interest in both.

There is no question that mimetic desire is the matrix of Flores' romance. Desires are being copied but never overly avowed, which lends itself for the tragicity that occurs at the dénouement. Desire, as Gerli aptly notes, is the catalyzer of human actions and behavior. Antonio Gargano ("Introducción", 6364 ) points out the combination of Boccaccio and Flores' stories. The dovetailing, however, occurs also on the interpersonal romantic level. The two couples form "triangular" desire that the reader can readily identify through Girard's epistemic methodologies. Grimalte and Gradissa mimic the desires of their models/obstacles/mediators to the extent that all traces of desire for each other are completely obliterated, metaphorically expressed through the great physical distance that separates them at the end of the novel. Grimalte

${ }^{23}$ Waley ("Introduction", 45) clarifies: "the speaker of the verse, from the sense and from the gender of the adjectives, is clearly Grimalte, although the introductory sentence seems to imply that it is Fiometa".

Medievalia 48, 2016, pp. 131-156 
travels to the remote wilderness of Asia to purge his imitative desire for Fiometa with his double (and desired) Pánfilo (Folger, Images in Mind, 95). And Gradissa categorically rejects Grimalte under the fallacious sophism that Grimalte fails at his quest, attesting to Waley's insightful observation that she would have rejected her suitor regardless of the outcome of his pandering mission. Gradissa, however, was forced to make up an excuse, for she could not admit her desire for Pánfilo because, as Girard (Violence, 146) notes, it amounts to admitting her lack of ontological originality. The only character whose desire and passion remained unchanged throughout the story was Fiometa's for Pánfilo, and her suicide attests to her unswerving devotion (Grieve, Desire and Death, 92). ${ }^{24}$ Walde Moheno ("La experimentación", 76) thought that Flores could have entitled his romance "Tratado de Fiometa y Pánfilo". Based on the preponderance of 154 Gradissa's desire for Pánfilo and Grimalte's for Fiometa, we could push the analogy further and suggest that Flores could have named his sentimental romance Tratado de Pánfilo y Gradissa or Tratado de Grimalte y Fiometa.

\section{BIBLIOGRAFÍA}

Brownlee, Marina S., The Severed Word: Ovid's Heroides and the Novela Sentimental, Princeton: Princeton University Press, 1990.

Castro Lingl, Vera, "Fiometa’s Suicide in Grimalte y Gradissa”, Journal of Hispanish Research, 1:3, 1993, 335-348.

Cirlot, Victoria, "El amor de lejos y el valor de la imagen. Elaboración y negación del mito del amor en la Europa medieval”, en José Ignacio de la Iglesia Duarte y José Luis Martín Rodríguez (coords.), Memoria, mito y realidad en la historia medieval, XIII Semana de Estudios Medievales, Nájera, 2002, Nájera: Instituto de Estudios Riojanos, 2003, 281-310.

Cvitanovic, Dinko, La novela sentimental española, Madrid: Prensa Española, 1973.

Deyermond, Alan, Tradiciones y puntos de vista en la ficción sentimental, México: Universidad Nacional Autónoma de México, 1993.

Deyermond, Alan, "Las innovaciones narrativas en el reinado de los reyes católicos," Revista de Literatura Medieval, VII, 1995, 93-105.

Flores, JuAn DE, Grimalte y Gradissa, ed. de Carmen Parrilla, Alcalá de Henares: Centro de Estudios Cervantinos, 2008.

24 Pánfilo himself discovers the truthfulness of her words through her suicidal action, as he mournfully confesses to Grimalte before he departs for Asia: "Y si este presumir por el contrario acaesció en aquélla, que cierto, más era su fe que su lengua lo dezía” (195).

Medievalia 48, 2016, pp. 131-156 
Flores, JuAn de, La Historia de Grisel y Mirabella, ed. de Pablo Alcázar López y José A. González Núñez, Granada: Don Quijote, 1983.

Folger, Robert, Images in Mind: Lovesickness, Spanish Sentimental Fiction \&" "Don Quijote”, North Carolina: North Carolina University Press, 2002.

Frye,Northrop, Secular Scripture and Other Writings on Critical Theory 1976-1991, ed. de Joseph Adamson y Jean Wilson, Toronto: University of Toronto Press, 2006, 71-72.

Gargano, Antonio, "Introducción", en Juan de Flores, "Triunfo de amor", ed. de Antonio Gargano, Pisa: Giardini, 1981.

Girard, René, To the Double Business Bound, Baltimore: The Johns Hopkins University Press, 1978.

GIRARD, RenÉ, Violence and the Sacred, Baltimore: The Johns Hopkins University Press 1979.

Girard, René, "Myth and Ritual in Shakespeare: A Midsummer Night's Dream", en Josué Hariri (ed.), Textual Strategies: Perspectives in Post-Structuralist Criticism, Ithaca: Cornell University Press, 1979, 189-214.

Girard, René, Deceit, Desire, and the Novel, trans. Yvonne Freccero. Baltimore: The Johns Hopkins University Press, 1984.

Girard, René, The Theater of Envy, Exeter: Short Run Press, Ltd., 2000.

Gómez Redondo, Fernando, "De la imaginación a la ficción en el Libro de Fiameta”, Romance Quarterly, 50:4, 2003, 243-257.

Grieve, Patricia, Desire and Death in the Spanish Sentimental Romance, Newark: Juan de la Cuesta, 1987.

Haywood, Louise M., “Gradissa: a fictional female reader in/of a male author's text”, Medium Aevum, 61:4, 1995, 85-99.

Lacarra, María Eugenia, "Juan de Flores y la ficción sentimental”, Actas del IX Congreso de la Asociación Internacional de Hispanistas. August 18-23 1986, Berlin, Frankfurt am Main: Vervuert, 1989, 223-233.

López GonzÁLEZ, Luis F., "The Defection of the Word: Violence and Death in Grisel y Mirabella" [currently under review]

López GonzÁlez, Luis F., "Grimalte and Gradissa’s Doubling through Mimetic Desire and the Elimination of Differences" [in press].

López GonzÁlez, Luis F., "Mirabella’s Deadly Gaze: the Force that Destabilizes the State's Power in Grisel y Mirabella", Viator [in press].

Macpherson, IAN, "The Game of Courtly Love: Letra, Divisa, and Invención at the Court of the Catholic Monarchs", en Michael Gerli y Julian Weiss (eds.), Poetry at Court in Trastamaran Spain: From the Cancionero de Baena to the "Cancionero General", Tempe: Medieval \& Renaissance Texts \& Studies, 1998, 95-110.

Madrigal, Alfonso de, Breviloquio de Amor e Amiçiçia, en Tratados de amor en el entorno de Celestina (siglos Xv-Xvi), ed. de Pedro M. Cátedra, Miguel M. 
García-Bermejo, Consuelo Gonzalo García, Inés Ravisini y Juan Miguel Valero, Madrid: Sociedad Estatal España Nuevo Milenio, 2001, 11-30.

Rojas, Fernando de, La Celestina, ed. Dorothy S. Severin, Madrid: Cátedra, 2008. SENA DE, IsABEL, “'Subita volvitrice delle cose mondane': De la Elegia di madonna Fiammetta de Boccaccio a Juan de Flores y Hélisenne de Crenne", en Juan Paredes (ed.), Actas del V Congreso de la Asociación Hispánica de Literatura Medieval, September 27- October 1, 1993, Granada: Universidad de Granada, 1995, t. 4, 335-350.

Severin, Dorothy S., "Introducción”, en Fernando de Rojas, La Celestina, ed. Dorothy S. Severin, Madrid: Cátedra, 2008.

Severin, Dorothy S., "Audience and Interpretation: Gradisa the Cruel and Fiometa the Rejected in Juan de Flores's prosimetrum, Grimalte y Gradisa", en Louise M. Haywood (ed.), Cultural Contexts/Female Voices, London: Queen Mary and Westfield College, 2000, 63-71.

Sutherland, Madeline, "Mimetic Desire, Violence and Sacrifice in the Celestina," Hispania, 86:2, 2003, 181-190.

Spitzer, Leo, L'amour lointain de Jaufré Rudel et le sens de la poésie des troubadours, Chapel Hill, 1944 [Revised in Romanische Literaturstudien 1936-1956, 363417, Tübingen, 1959].

WALde Moheno, Lillian von DER, "La experimentación literaria del siglo XV: a propósito de Grimalte y Gradissa”, en Joseph J. Gwara (ed.), Juan de Flores: Four Studies, London: University of London, 2005, 75-90.

Waley, Pamela, “Introduction”, Juan de Flores, Grimalte y Gradissa, London: Tamesis, 1971.

Walthaus, Rina, "Espacio y alienación en Grimalte y Gradissa de Juan de Flores", Letradura. Estudios de Literatura Medieval, Scriptura, 13, 1997, 5-18.

Weissberger, BARbara, "Authors, Characters and Readers in Grimalte y Gradissa", en R. E. Surtz y N. Winerth (eds.), Creation and Re-creation: Experiments in Literary Form in Early Modern Spain. Studies in honor of Stephen Gilman, Newark: Juan de la Cuesta, 1983, 61-76.

Weissberger, Barbara, "Resisting Readers and Writers in the Sentimental Romances and the Problem of Female Literacy", en Joseph J. Gwara y E. Michael Gerli (eds.), Studies of the Spanish Sentimental Romance 1440-1550, London: Tamesis, 1997, 173-190.

Wright, DiAne M., "Readers, Writers, and Lovers in Grimalte y Gradissa”, en Evelyn Mullally y John Thompson (eds.), The Court and Cultural Diversity: Selected papers from the Eighth Triennial Congress of the International Courtly Literature Society International Courtly Literature Society, Cambridge: Cambridge University Press, 1997, 229-238. 